\title{
Effects of Cellulytic Enzymes on Phytophthora cinnamomi
}

\author{
A. J. Downer, J. A. Menge, and E. Pond
}

First author: University of California, Cooperative Extension, 669 County Square Drive, Suite 100, Ventura 93003; and second and third authors: University of California, Department of Plant Pathology, Riverside 92521.

Accepted for publication 1 June 2001.

\begin{abstract}
Downer, A. J., Menge, J. A., and Pond, E. 2001. Effects of cellulytic enzymes on Phytophthora cinnamomi. Phytopathology 91:839-846.

Two enzyme systems, cellulase ( $\beta$-1,4-glucanase) and laminarinase ( $\beta$-1,3-glucanase), were added to soil extracts to simulate (in vitro) lytic components found in mulches suppressive to Phytophthora cinnamomi. Concentration ranges of each enzyme were incubated with Phytophthora cinnamomi mycelium, zoospores, zoospores cysts, and zoospore-infected excised roots to evaluate the roles of each enzyme in potential control of avocado root rot disease. Cellulase significantly retarded the development of zoosporangia and chlamydospores when mycelia were incubated in soil extract containing the enzyme at concentrations greater than 10 units $/ \mathrm{ml}$. Zoospore production was also reduced by cellulase but not

by laminarinase. Laminarinase had little effect on zoosporangia or chlamydospore formation. At high concentrations, laminarinase was consistently more effective at preventing encystment than cellulase. Chlamydospores preformed in root tips were immune to the lytic effects of all treatments except cellulase at 100 units $/ \mathrm{ml}$. Zoospores placed in enzyme solutions and plated on a selective medium survived high cellulase concentrations and formed colonies, but there were fewer surviving zoospores when laminarinase was present at greater than 10 units $/ \mathrm{ml}$. Low concentrations of cellulase stimulated infection of excised roots, however, low concentrations of laminarinase prevented infection. Cellulase and laminarinase have different effects on the structures of the Phytophthora cinnamomi life history, however, each enzyme may have a role in reduction of inoculum.
\end{abstract}

Lysis of hyphae or spore stages is a frequently cited mechanism of antagonism used by fungi and bacteria against soilborne plant pathogens growing in highly organic soils $(9,22)$. Lysis was noted by Broadbent and Baker (7) as an important component of the Ashburner system of biological control of Phytophthora cinnamomi Rands. in Australia. The Ashburner system consists of the use of copious quantities of fresh organic mulches that contain large amounts of cellulose in an attempt to recreate jungle soils that were suppressive to Phytophthora cinnamomi. The Ashburner method was able to recreate a lytic soil environment suppressive to Phytophthora cinnamomi in Australian avocado groves. Amensalism or lysis of Phytophthora propagules by antibiotics is common and is caused by many different kinds of organisms in soil $(16,21)$. Antibiotics, and other antifungal compounds, may be produced exogenously and accumulate in soil, thus, producing a suppressive environment harmful to zoosporangia, zoospores, oospores, chlamydospores, and mycelium of Phytophthora cinnamomi $(9,14)$.

The degradation of fungal cell walls requires enzymes that can hydrolyze polymers of glucose with various glycosidic linkages $(4,6)$. Chitinase and $\beta-1,3$-glucanase are recognized as important fungus cell wall-dissolving enzymes because they attack the most common cell wall-forming polymers in fungi, $\beta-1,3$ glucan and chitin $(5,12,17,19,26,28)$. Phytophthora cinnamomi is a unique member of the rhizosphere mycoflora because its cell walls are composed of cellulose ( $\beta$-1,4-linked glucans) and $\beta-1,3-$ and $\beta$-1,6-linked glucans $(4,5,35)$. Cyst cell walls of Phytophthora are composed largely of $\beta-1,4$-glucan linkages $(>30 \%)$, whereas the hyphal thallus has a lower composition of cellulose $(11 \%)$. There is little published data on glucan content of chlamydospores. However, Bartnicki-Garcia and Wang (6) reported that $\beta$-glucans

Corresponding author: A. J. Downer; E-mail address: ajdowner@ucdavis.edu

Publication no. P-2001-0716-01R

(C) 2001 The American Phytopathological Society are the primary wall component. Cellulose microfibrils in Phytophthora cell walls should make the fungus susceptible to enzymatic destruction by cellulases $(\beta-1,4$-glucanases) present in organic litter layers. In vitro work on Phytophthora protoplast production for genetic studies has shown that cellulases and laminarinase will completely dissolve the cell wall (14).

Penicillium funiculosum Thom. causes lysis of Phytophthora cinnamomi in organic container media, resulting in its biological control (15). The most effective isolate of Penicillium funiculosum was also the most lytic. In addition, cellulases produced by two actinomycetes lyse Phytophthora cinnamomi, thereby suppressing disease in Banksia grandis Willd. (13). Cellulases and $\beta$-1,3-glucanases produced by Epicoccum purpurascens Ehrenb. have also been implicated in the control of Phytophthora cinnamomi (8). Although cellulases produced by members of the Agaricales are postulated to play a role in control of Phytophthora cinnamomi (16), there has been little further research on these effects. Although these investigations associated cellulase-producing organisms with control of Phytophthora cinnamomi, no experiments have described the specific effects of cellulytic enzymes directly on production or survival of Phytophthora cinnamomi reproductive structures and spores. The purpose of this study was to determine the effect of cellulase and laminarinase enzymes on Phytophthora cinnamomi life stages and the impact in infection of susceptible avocado (Persea americana Mill.) roots.

\section{MATERIALS AND METHODS}

All enzyme experiments were completed in soil extracts and enzyme extract dilutions with the final $\mathrm{pH}$ adjusted to 6.8 (to simulate field conditions). Adjustments to extract $\mathrm{pH}$ were made with $1.0 \mathrm{~N}$ sodium hydroxide. Soil extract was prepared by suspending $10 \mathrm{~g}$ (dry wt) of soil in 1 liter of deionized water. The soil used for extracts was a Rincon silty clay loam (fine, montmorillonitic, thermic Mollic Haploxerafls) collected from an avocado grove in Somis, CA. The chemistry of the soil was characterized as $\mathrm{pH}$ 6.8, electrical conductivity $3.3 \mathrm{dS} / \mathrm{m}$, 
$26.9 \mathrm{meq} / \mathrm{liter}$ of $\mathrm{Ca}, 11.8 \mathrm{meq} / \mathrm{liter}$ of $\mathrm{Mg}, 7.15 \mathrm{meq} / \mathrm{liter}$ of $\mathrm{Na}$, $0.126 \% \mathrm{~N}$ (total), $11 \mathrm{ppm}$ of $\mathrm{NO}_{3}, 20.6 \mathrm{ppm}$ of $\mathrm{P}$ (Olsen analysis), $256 \mathrm{ppm}$ of $\mathrm{K}$, and $2.25 \%$ organic matter. The soil suspension was stored at $24^{\circ} \mathrm{C}$ for $24 \mathrm{~h}$, decanted to leave behind solids, and filtered through Whatman No. 1 filters.

Two enzymes were used in these experiments: cellulase $(\beta-1,4$ activity: 6.1 units $/ \mathrm{mg}$ ) derived from Penicillium funiculosum Thom. (Sigma Chemical Inc., St. Louis) and laminarinase ( $\beta-1,3$ activity: 2 units/mg) from Rhizoctonia solani Kühn. (Calbiochem Inc., La Jolla, CA). Enzymes were dissolved in soil extract at various concentrations expressed as units of activity. One unit of activity is the amount of enzyme required to liberate $1 \mu \mathrm{mol}$ of glucose from an appropriate substrate per milligram of enzyme per hour.

Isolate M-295 of Phytophthora cinnamomi, obtained from a replanted avocado grove in Somis, CA, was used in all studies. The stock culture was maintained on V8-juice agar (V8-C) (708 $\mathrm{ml}$ of $\mathrm{V} 8$ juice and $10 \mathrm{~g}$ of $\mathrm{CaCO}_{3}$ were centrifuged at $9,000 \mathrm{rpm}$ for $20 \mathrm{~min}$ to clarify the mixture; $200 \mathrm{ml}$ of the supernatant was mixed with $15 \mathrm{~g}$ of agar plus $800 \mathrm{ml}$ of deionized water) stored in the dark at $24^{\circ} \mathrm{C}$. Fresh cultures were prepared on
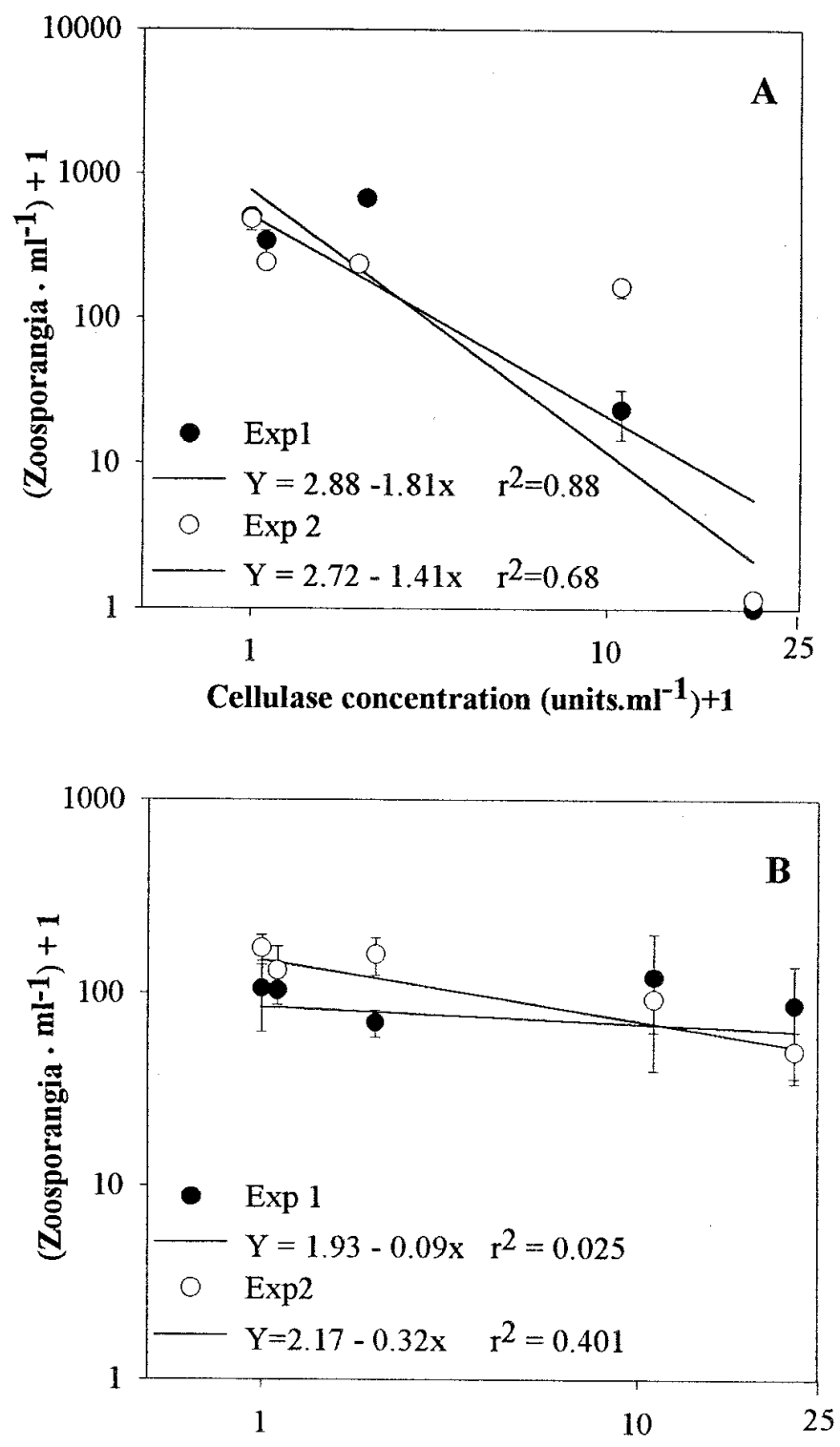

Laminarinase concentration (units $\cdot \mathbf{m l}^{-1}$ ) +1

Fig. 1. Effect of enzymes on zoosporangium production of Phytophthora cinnamomi. Bars are standard error of the mean of three replicates. this medium and grown at $24^{\circ} \mathrm{C}$ in the dark for 3 to 4 days prior to use for inoculum preparation.

Phytophthora cinnamomi sporangia and zoospores were produced by transferring 5-mm-diameter disks from the growing edge of 3-day-old cultures (on V8-C agar) to $10 \mathrm{ml}$ of sterile halfstrength V8-C broth (23) for 3 days in the dark. The mycelial mats were rinsed three times with distilled water before incubation in enzyme and soil extract solutions or further preparation for zoospore release. Zoospore suspensions were prepared by incubation of the rinsed mycelial mats in soil extract (5 to $10 \mathrm{ml}$ ) at $24^{\circ} \mathrm{C}$ under fluorescent lights for 2 days to stimulate sporangial production (3). Mats were washed three times with deionized water and incubated at $4^{\circ} \mathrm{C}$ for $30 \mathrm{~min}$ in $5 \mathrm{ml}$ of deionized water. Plates were removed from cold incubation and incubated at room temperature $\left(24^{\circ} \mathrm{C}\right)$ for an additional $30 \mathrm{~min}$. Zoospore release was quantified microscopically with an eelworm counting chamber (Hawksley \& Sons Ltd., Lancing West Suffex, England). Two setups of the eelworm chamber were averaged for analysis. To facilitate counting of zoospores, they were first encysted by spinning at full speed on a rotary vortex for $1 \mathrm{~min}$. Viability was confirmed by transferring spores onto PARPH medium (per liter corn meal agar medium: $0.02 \mathrm{~g}$ of delvocid; $0.25 \mathrm{~g}$ of ampicillin; $0.01 \mathrm{~g}$ of rifampicin; $0.10 \mathrm{~g}$ of pentachloronitrobenzene; and $0.075 \mathrm{~g}$ of hymexazol) at $24^{\circ} \mathrm{C}$ in the dark for 2 to 3 days (20).

All experiments were conducted twice using a randomized block design with a minimum of three replicates. In some experiments, five replicates were used. Data were plotted on $\log _{10}$ scale, and linear regressions were used to describe the relationship of enzyme concentration to the effects on Phytophthora cinnamomi propagules. Linear regressions were calculated and plotted with Sigma Plot 4.01 (SPSS Inc., San Rafael, CA). All experiments were repeated twice.

Enzyme effects on zoosporangium, zoospore, and chlamydospore formation. Sporangia, zoospores, and chlamydospores were prepared from mycelium as previously described and incubated in soil extract with either cellulase or laminarinase at the following concentrations: $0.0,0.1,1.0,10.0$, and 25.0 units of enzyme per $\mathrm{ml}$ of soil extract under fluorescent light at $24^{\circ} \mathrm{C}$ for 3 days. Mycelia were rinsed with deionized water three times before release and counting of zoospores. Zoospores were released, encysted, and counted as described previously. Total zoospore release was calculated by multiplying the dilution factor by the number of spores counted per milliliter.

After spore release, the mycelial mats were ground in a Waring blender for $25 \mathrm{~s}$ on high speed. One milliliter of the chopped mycelial suspension was loaded into the counting chamber. Zoosporangia were counted as described previously. Both empty and unreleased zoosporangia were counted. Chlamydospores that were produced on the same mycelium were counted at the same time as zoosporangia. Three replications were used, and each experiment was repeated.

Enzyme effects on zoospore encystment. Zoospores were prepared as previously described in soil extract without enzymes. Spores were quantified in the counting chamber and placed in either cellulase or laminarinase solutions at the following concentrations: $0.0,0.1,1.0$, and 10.0 units of enzyme per $\mathrm{ml}$ of soil extract. Swimming zoospores were incubated for $30 \mathrm{~min}$ at $24^{\circ} \mathrm{C}$ in the solutions in standard $(15 \mathrm{ml})$ test tubes. The tubes were vortexed for 1 min to stop swimming and stimulate encystment. Cysts were counted in the counting chamber as described previously. Three replications were used, and each experiment was repeated.

Encystment on excised roots. An excised root assay was used to assess zoospore ability to begin the process of infection. Mycelia were labeled with fluorescent brighteners as described by Tsao (31), with the following modifications: prior to preparation of zoospores, Phytophthora cinnamomi mycelium was treated with fluorescent brightener 28 (disodium salt of 4,4'b-bis(4-anilino-6-diethylamino-s-triazin-2-ylaminoo-2,2' -stilbene-disulfonic acid) $2 \mathrm{~g} /$ liter) 
(Sigma Chemical) and incubated at $24^{\circ} \mathrm{C}$ in the dark for $4 \mathrm{~h}$. After incubation, mycelia were rinsed three times with deionized water. Zoospores were prepared and released as described previously without enzymes. Root tips (1 $\mathrm{cm}$ length) harvested from container-grown seedlings of susceptible avocado cv. Topa Topa were washed with deionized water and placed (three each) in petri plates $(15 \times 60 \mathrm{~mm})$. Zoospores suspensions $\left(10^{4}\right.$ spores per $\left.\mathrm{ml}\right)$ were added simultaneously with enzyme solutions to create $5 \mathrm{ml}$ of the following dilutions of enzymes: $0.0,0.001,0.01,0.1,1.0$, and 10.0 units per $\mathrm{ml}$ of cellulase or laminarinase in experiment 2 . In experiment 1 , higher concentrations of 25,50 , and 100 units were used in addition to those mentioned above. Zoospores were allowed $2 \mathrm{~h}$ to encyst on root tips at $24^{\circ} \mathrm{C}$ in ambient lighting conditions. Roots were removed from solutions and examined microscopically. Zoospore cysts were counted on $1-\mathrm{cm}^{2}$ surface of each root at $\times 125$ magnification under UV illumination with a Zeiss 14 microscope (Carl Zeiss, Thornwood, NY) set up for fluorescence microscopy. A blue $450-$ to $490-\mathrm{nm}$ filter as well as a LP 520 barrier filter were used. Five replications were used, and each experiment was repeated.
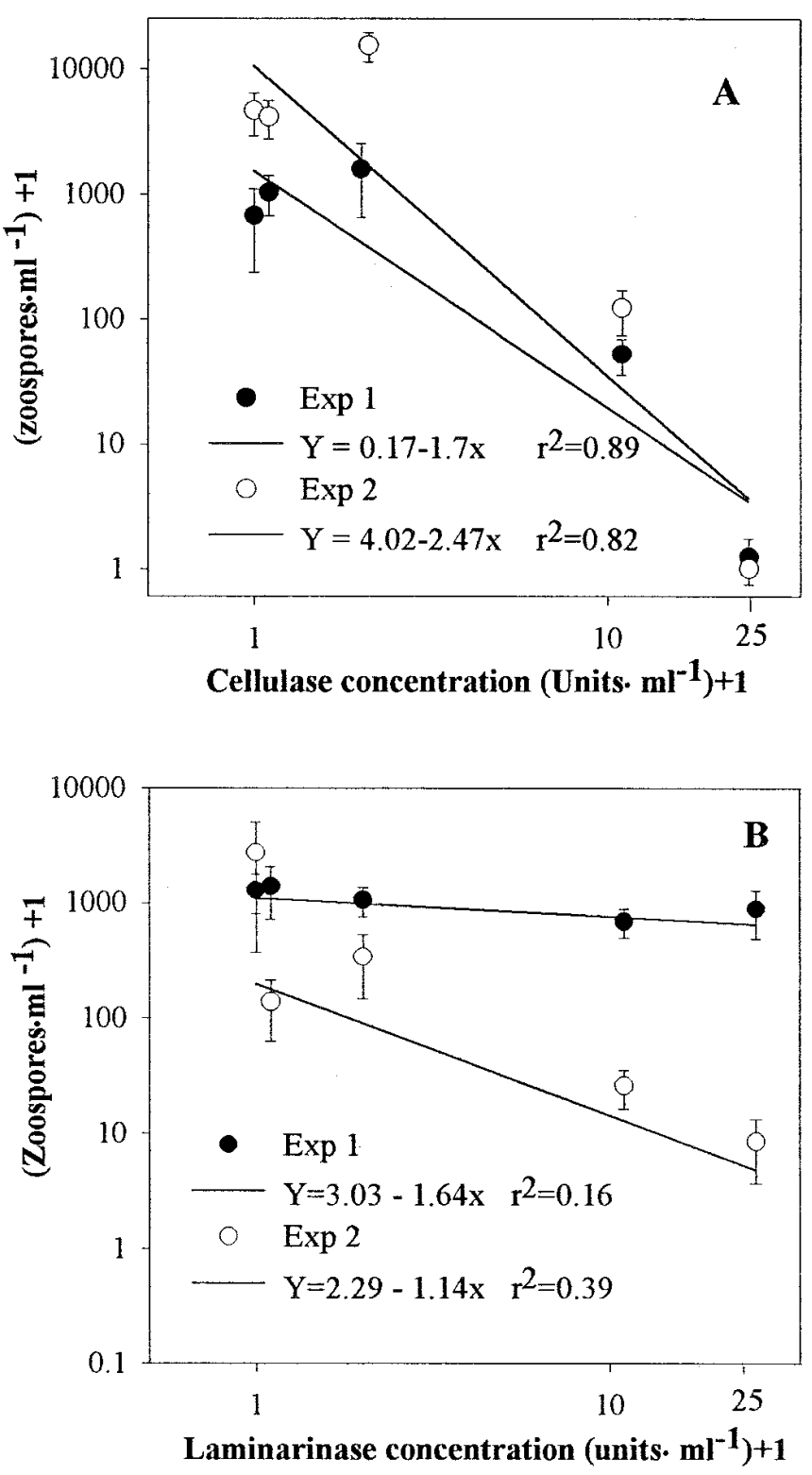

Fig. 2. Effect of enzymes on zoospore production of Phytophthora cinnamomi. Bars are standard error of the mean of three replicates.
Chlamydospore survival in roots. To test the effects of enzymes within roots, excised avocado root tips were infested with Phytophthora cinnamomi as follows. Root tips $(1 \mathrm{~cm})$ of avocado cv. Topa Topa were harvested from vigorous seedlings and sanitized in $0.25 \%$ sodium hypochlorite with slow agitation on a stirring plate for $15 \mathrm{~min}$. Root tips were washed with $250 \mathrm{ml}$ of sterile deionized water four times. Root tips were transferred to PARPH medium (25 to 50 tips per plate), and several disks of Phytophthora cinnamomi from a 3-day-old colony on V8-C medium were placed on the plate. The plates were incubated in the dark at $24^{\circ} \mathrm{C}$ for 10 days to allow complete colonization of the root tips. Roots were removed aseptically onto autoclaved Whatman No. 1 filter papers in $15-\mathrm{cm}$ glass petri dishes. Roots were allowed to slowly dry in the glass plates for 14 days and were checked intermittently for chlamydospore formation.

After formation of chlamydospores in roots, five root tips were placed in petri plates $(15 \times 60 \mathrm{~mm})$ and $5 \mathrm{ml}$ of enzyme solution was added to each plate in the following concentrations: cellulase $=$ $0.0,1.0,10.0$, and 100.0 units $/ \mathrm{ml}$; and laminarinase $=0.0,0.1,1.0$, and 10.0 units $/ \mathrm{ml}$. Three replications were used for each treat-
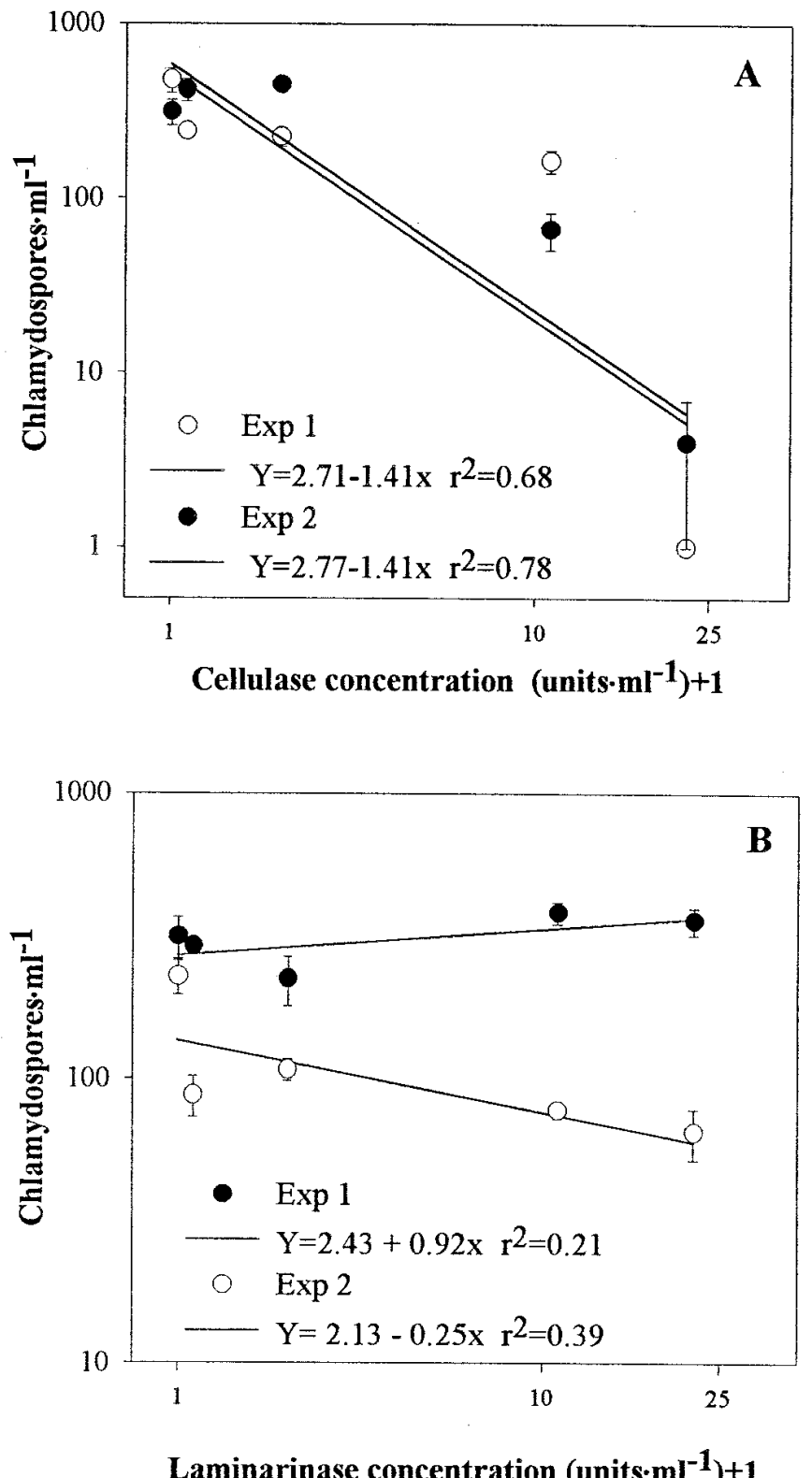

Fig. 3. Effect of enzymes on chlamydospore production of Phytophthora cinnamomi. Bars are standard error of the mean of three replicates. 
ment. Plates were incubated at $24^{\circ} \mathrm{C}$ for 3 days in the dark. Enzyme treatments were washed from the roots with distilled water, and all of the root tips in each treatment (five replications) were placed in a Waring blender and ground in $20 \mathrm{ml}$ of deionized water for $1 \mathrm{~min}$. Two hundred microliters of the ground root solution was added to each of two plates containing PARPH medium. PARPH plates were incubated in the dark at $24^{\circ} \mathrm{C}$ for 2 days. Colonies of Phytophthora cinnamomi were counted and averaged before further analysis. Five replications were used, and each experiment was repeated.

Zoospore survival. Zoospores were prepared as previously described in absence of enzyme treatments. Zoospore suspensions $\left(10^{4}\right.$ spores per $\left.\mathrm{ml}\right)$ were pipetted into a concentration range of each of two enzymes $(0.0,0.1,1.0,10.0,25,50$, and 100 units $/ \mathrm{ml})$. Zoospores were allowed to swim in enzyme solutions for $30 \mathrm{~min}$ at $24^{\circ} \mathrm{C}$ in ambient light conditions in test tubes. Zoospores were transferred (100 $\mu \mathrm{l}$ of zoospore per enzyme suspension) onto PARPH medium and gently spread with a glass rod. No vortexing was used to stimulate encystment. Phytophthora cinnamomi colonies were counted after plates were incubated in the dark at $24^{\circ} \mathrm{C}$ for 2 days. Three replications were used, and each experiment was repeated.

\section{RESULTS}

Enzyme effects on zoosporangium, zoospore, and chlamydospore formation. Cellulase had a pronounced effect on Phytophthora cinnamomi spore formation. Reduction of zoosporangia, zoospores, and chlamydospores were all highly correlated following analysis by linear regression and treatment comparisons by analysis of variance (ANOVA) $(P<0.01$ or greater) (Figs. 1A, $2 \mathrm{~A}$, and $3 \mathrm{~A})$. At high concentrations ( $>10.0$ units $/ \mathrm{ml})$, cellulase consistently prevented zoospore and chlamydospore formation (Figs. 1A, 2A, and 3A). At concentrations greater than 25-cellulase units/ml, the mycelium was significantly disrupted (data not shown). At 100 units of cellulase per ml, Phytophthora cinnamomi mycelium were so disrupted that no hyphae or spores were left intact (Fig. 4A), whereas mycelium incubated only in soil extract with enzyme remained healthy (Fig. 4B). At low concentrations (1 unit $/ \mathrm{ml}$ ), cellulase stimulated formation of zoosporangia, zoospores, and chlamydospores in one of the two experiments (significant ANOVA at $P<0.01$ ) (data not shown).

Laminarinase had little effect on formation of zoosporangia, zoospores, and chlamydospores (Figs. 1B, 2B, and 3B). Linear regressions and other comparisons of laminarinase concentration with sporangium, zoospore, or chlamydospore counts were not significant according to ANOVA.

Enzyme effects on zoospore encystment. Increasing concentrations of both cellulase (in one repetition of the experiment only) and laminarinase were correlated with decreased cyst formation (significant linear regressions at $P<0.01$ ) (Fig. 5). Although response to cellulase was less consistent, laminarinase consistently reduced cyst formation as the concentration of enzyme increased to 10 units.

Encystment on excised roots. Zoospore infection of excised roots (a precursor to infection) was increased by low concen-
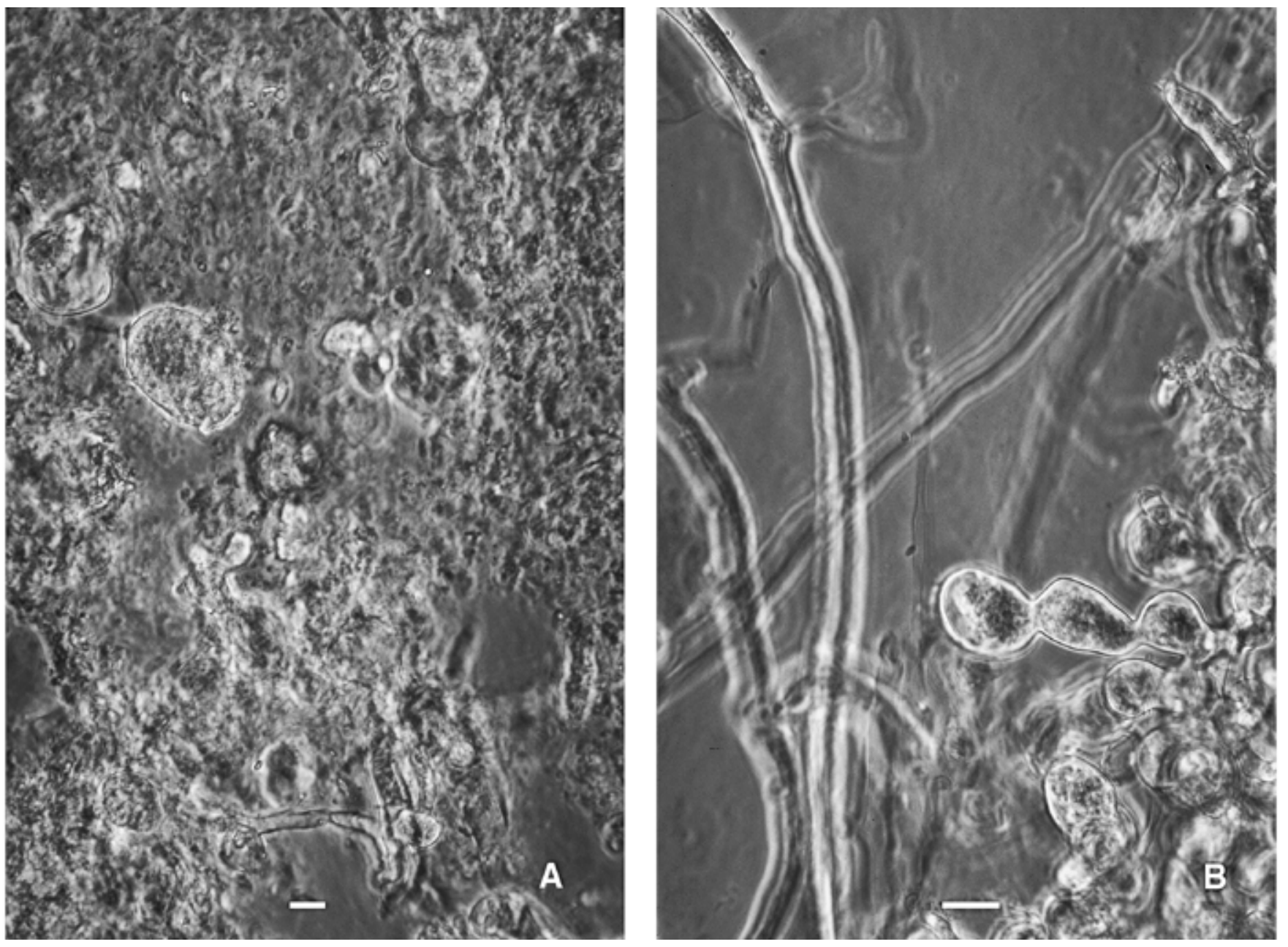

Fig. 4. Effects of cellulase on mycelium of Phytophthora cinnamomi. A, Mycelium incubated in cellulase and soil extract (100 units/ml); and B, mycelium in soil extract alone. Bar represents $10 \mu \mathrm{m}$. 
trations of cellulase in one experiment but not in a repeat experiment (single degree of freedom contrasts and ANOVA, $P<$ 0.05) (Fig. 6A). Cellulase reduced encystment at higher rates ( $>25$ units $/ \mathrm{ml})$. Laminarinase reduced infection of excised avocado roots at low concentrations $(0.1 \mathrm{unit} / \mathrm{ml})$ in both experiments (Fig. 6B). Reduction of zoospore encystment on excised roots by laminarinase was the most pronounced effect in the study (Fig. 7A and B).

Chlamydospore survival in roots. Germination of preformed chlamydospores (inside roots) was stimulated by cellulase concentrations of 10 units $/ \mathrm{ml}$, unaffected by lower concentrations, and at 100 units/ml cellulase, chlamydospores were killed almost entirely (100-unit concentration treatment different from other treatments according to ANOVA and significant linear regressions, $P<0.01$ ) (Fig. 8A).

Laminarinase had no deleterious effect on chlamydospores in the range of activity effective on zoospores $(<10$ units $/ \mathrm{ml})$. At 10 units $/ \mathrm{ml}$, laminarinase enhanced chlamydospore germination significantly (according to ANOVA and significant linear regressions, $P<0.05$ ) in one experiment but not the other (Fig. 8B).

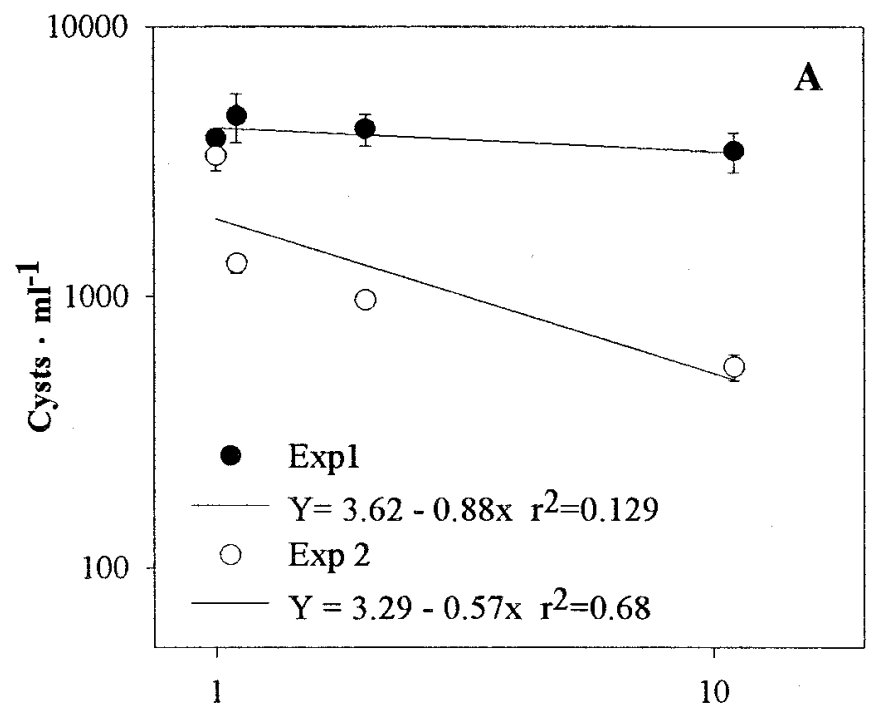

Cellulase concentration (units $\left.\cdot \mathrm{ml}^{-1}\right)+1$

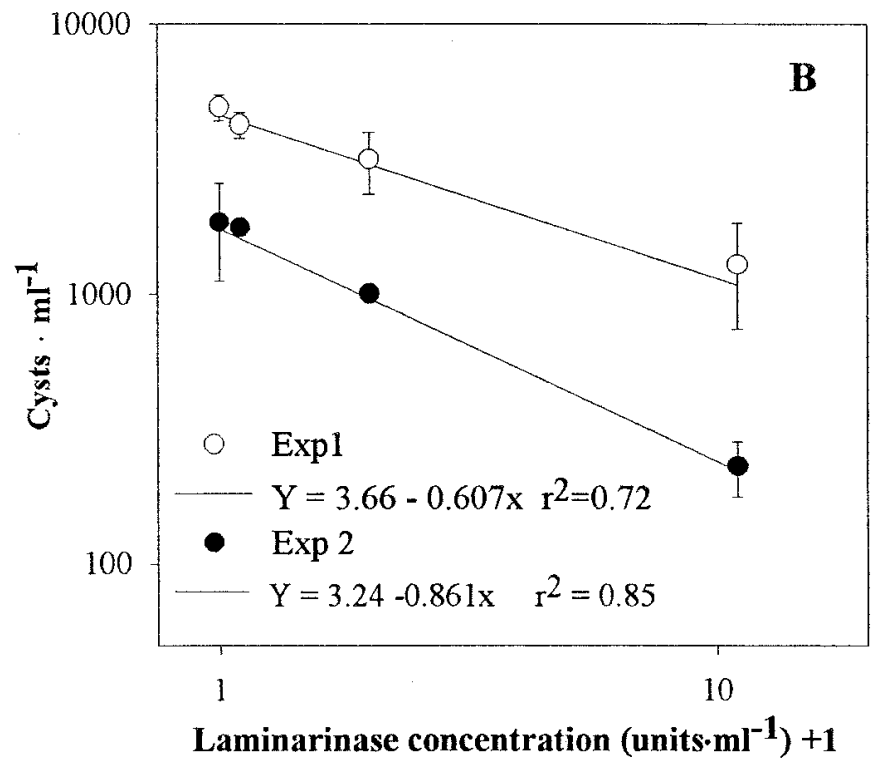

Fig. 5. Effect of enzymes on zoospore encystment of Phytophthora cinnamomi. Bars are standard error of the mean of three replicates.
Zoospore survival. Zoospores released to swim in cellulase survived and formed colonies on PARPH medium after a short incubation at room temperature (Fig. 9A). There was no dose response in one experiment but in another survival increased with increasing cellulase concentrations.

Laminarinase reduced survival and colony formation of Phytophthora cinnamomi as the concentration increased (linear regressions significant at $P<0.05$ ) (Fig. 9B). At 10 units $/ \mathrm{ml}$, laminarinase significantly reduced survival rates (significant ANOVA and single degree of freedom contrast, $P<0.05)$.

\section{DISCUSSION}

Phytophthora cinnamomi has a life history in which it produces several kinds of spores required for its survival and infection of susceptible hosts (34). Mycelia of this oomycete give rise to two asexual stages, chlamydospores, which are thick-walled spores that aid in survival, and zoosporangia (25). Zoosporangia and chlamydospores may geminate directly to form hyphae or produce more zoosporangia that under proper temperature and moisture
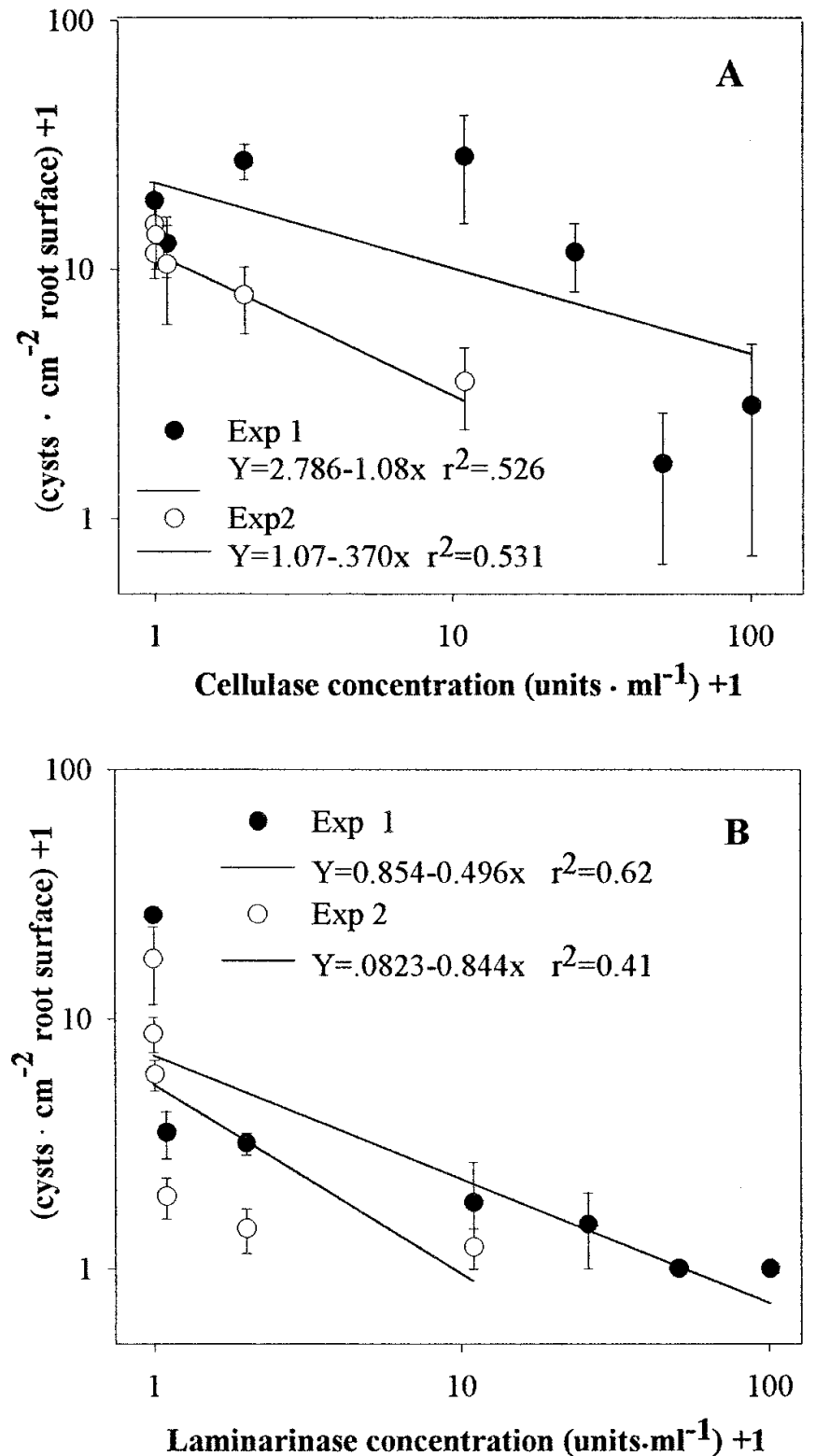

Fig. 6. Effect of enzymes on zoospore encystment on excised avocado roots by Phytophthora cinnamomi. Bars are standard error of the mean of five replicates. 
conditions produce motile zoospores (18). Although hyphae can infect roots, zoospores are the most common infective propagule of Phytophthora cinnamomi and, thus, the most important inoculum source $(14,34)$. However, for zoospores to successfully infect, they must survive chemical and biological environments in the soil and rhizosphere, locate a susceptible root, attach, encyst, germinate, and penetrate the root epidermis.

It is well documented that lysis of mycelium causes an increase in the formation of zoosporangia and chlamydospores of many species of Phytophthora $(22,24,30)$. If the lytic potential of soil is extreme, spore formation is prevented because the mycelium of Phytophthora cinnamomi is destroyed before spores can form (22). Although Fang and Tsao (15) attributed control of Phytophthora by Penicillium funiculosum to its lytic potential, enzyme activities were not measured. In this study, cellulase derived from Penicillium funiculosum completely dissolved mycelium at 50 to 100 units $/ \mathrm{ml}$, but at lower concentrations (1 unit $/ \mathrm{ml}$ ), zoosporangia and chlamydospore formation was increased. This is consistent with Malajczuk's (22) assertion that amensalistic antagonists of hyphae increase sporulation of Phytophthora cinnamomi. Low levels of antagonistic activity may thin hyphal walls, thus, stimulating sporulation, whereas high levels of activity destroy Phytophthora propagules or hyphae.

Microbial activity (probably bacteria or their metabolites) favors sporangia formation in Phytophthora cinnamomi (2,3,33). Although it is possible that some suppressive soils that retard the disease will lack the stimulatory bacteria necessary for sporangium development (22), it is more likely that Phytophthora cinna- momi suppressive soils are so antagonistic that the hyphae and spores are destroyed (14). Suppression also could be explained by a range of lytic enzyme concentrations that are present in soils and at the mulch-soil interface. In low organic matter soils with little substrate, enzyme activities are low or nonexistent $(11,29)$. Where enzymes are abundant in organic soil, Phytophthora may be reduced or eliminated (11).

Laminarinase ( $\beta$-1,3-glucanase) is extremely destructive to zoospores such that it may play a role in the suppression of Phytophthora in nature. Organisms producing $\beta$-1,3-hydrolytic glucanases are common inhabitants of highly organic soils $(11,21$, 28 ). In these soils (with glucanase and cellulase producing fungi), enzyme concentrations increase and so may the antagonistic potential of the soil. High populations of cellulytic fungi are most likely found in heavily mulched or highly organic soils. The relationship of fungal populations to in situ enzyme concentrations is an area that needs further investigation. These enzymes may be the important lytic factors in suppressive soils described by Broadbent and Baker (7) and Malajczuk (22) and extensively reviewed by Erwin and Ribeiro (14).

Organic matter has been recognized as a major contributor to biological control of Phytophthora diseases by many investigators $(7,9,22)$. Specific mechanisms for this control have not been determined; however, an association has been made with increases in microbial activity in highly organic systems. In this study, cellulase and laminarinase enzymes (which are commonly produced in mulches) $(10,11)$ were destructive to zoospores and other propagules. Biological control of Phytophthora spp. in mulch
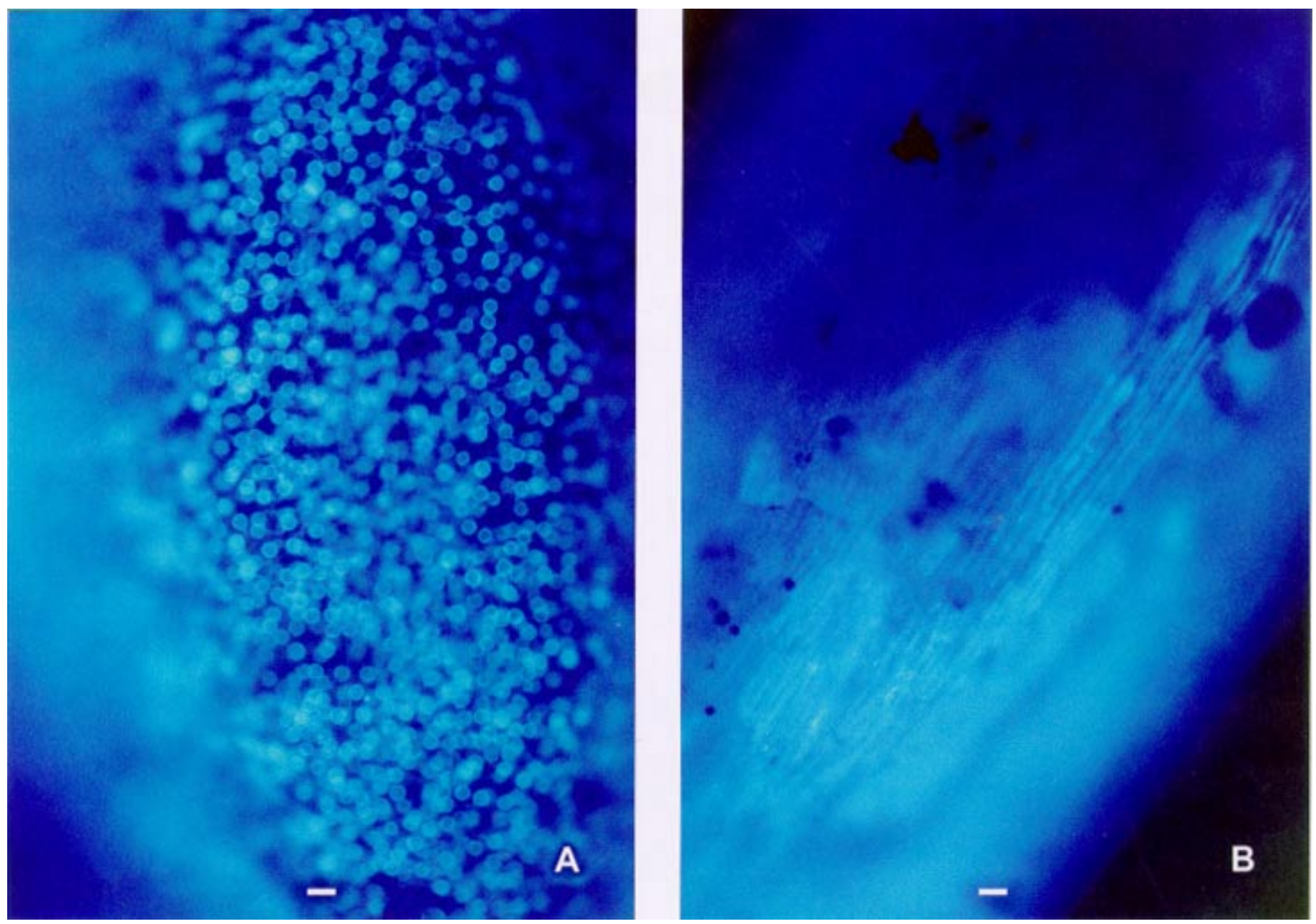

Fig. 7. Effects of laminarinase on encystment on excised avocado root tips. A, Root tip incubated with zoospores in soil extract; and $\mathbf{B}$, root tip incubated in 1 unit of laminarinase. Bar represents $10 \mu \mathrm{m}$. 
systems may be a by-product of natural litter/mulch decomposition processes that include not only enzymes but also growth and development of mulch microorganisms. Except for lignaceous barks (which require lignases), most organic matter is composed principally of cellulose and degraded by cellulases (32). Degradation of organic mulches requires a microbial community with cellulase-degrading enzyme systems $(1,27)$. In litter (a natural mulch), fungi comprise the greatest biomass of this community (27). Most fungal cell walls are rich in $\beta-1,3$ glucan (6), thus, mulches are a storehouse of extracellular enzymes such as cellulase, which is a result of initial attack of green tissues by saprophytic fungi and later glucanase, because fungi themselves are attacked as substrate within the mulch.

Zoospores contain large amounts of $\beta-1,3$ glucan (mycolaminarin), more than the sporangia that gave rise to them (5). This may explain zoospore susceptibility to laminarinase during infection of excised roots and the relative immunity of sporangia and hyphae to laminarinase treatment. Zoospores swim in distilled water for variable periods but can swim for up to several hours at $25^{\circ} \mathrm{C}$ before spontaneous encystment; however, rapid encystment is stimulated by agitation (18). Encystment requires that the naked

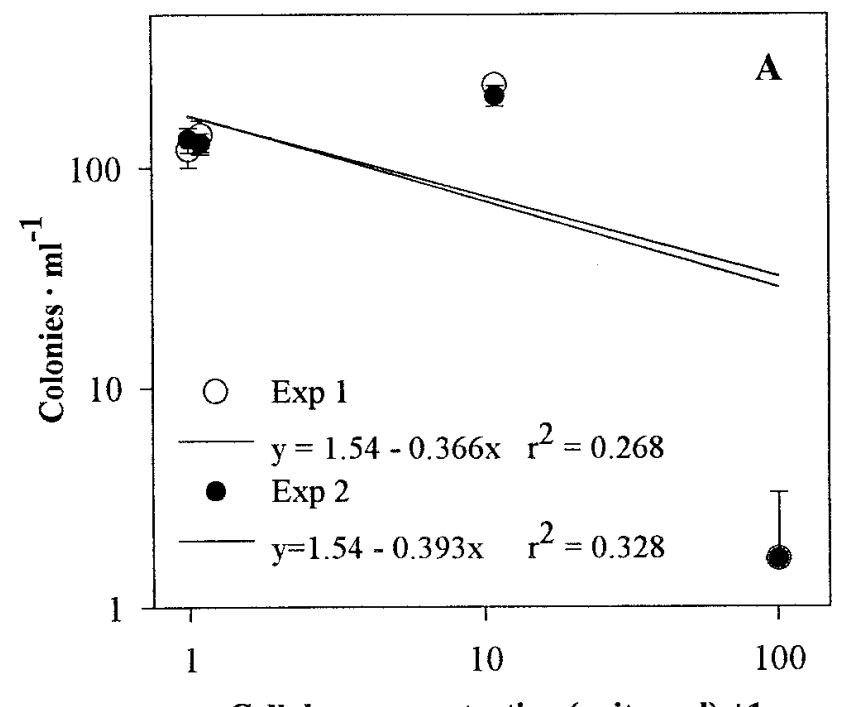

Cellulase concentration (units $\cdot \mathrm{ml})+1$

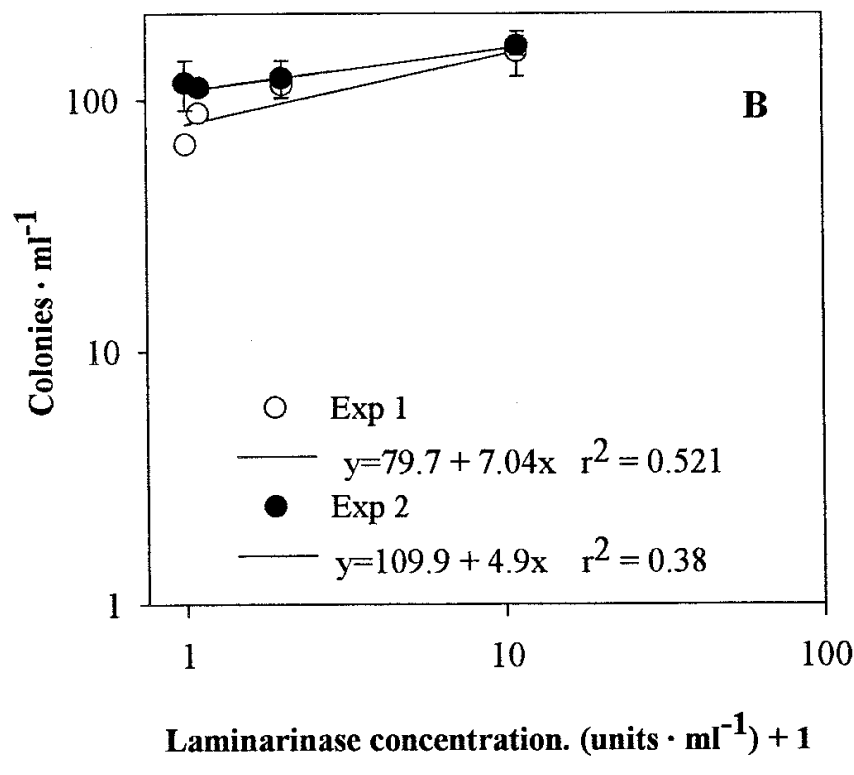

Fig. 8. Effect of enzymes on chlamydospore survival of Phytophthora cinnamomi in excised roots. Bars are standard error of the mean of five replicates. protoplast cell (zoospore) form a cell wall. Although cyst walls reportedly contain high concentrations of cellulose (6) in this study, they were most affected by laminarinase not cellulase. Cell wall assembly in Phytophthora cinnamomi cysts most likely requires synthesis of polymers with $\beta-1,3$ and $\beta-1,4$ as well as other linkages between glucose molecules. Thus, either enzyme could prevent cyst formation, however, it is unclear why one enzyme is more effective at disrupting the assembly process than the other. Cellulases and laminarinases are systems of enzymes comprised of exo- and endo-acting hydrolases as well as disaccharases (i.e., $\beta$-glucosidase in the cellulase system). Thus, an "enzyme process" that does not have all the components of the required system or has one component in low concentration has reduced efficacy of the tested hydrolase process (27). Zoospores suspended in cellulase and laminarinase enzymes and plated on agar medium survived high cellulase concentrations but not laminarinase. Because zoospores have no cell wall and thus no cellulose, they provide no substrate for attack by cellulase. Laminarinase seems to exhibit a
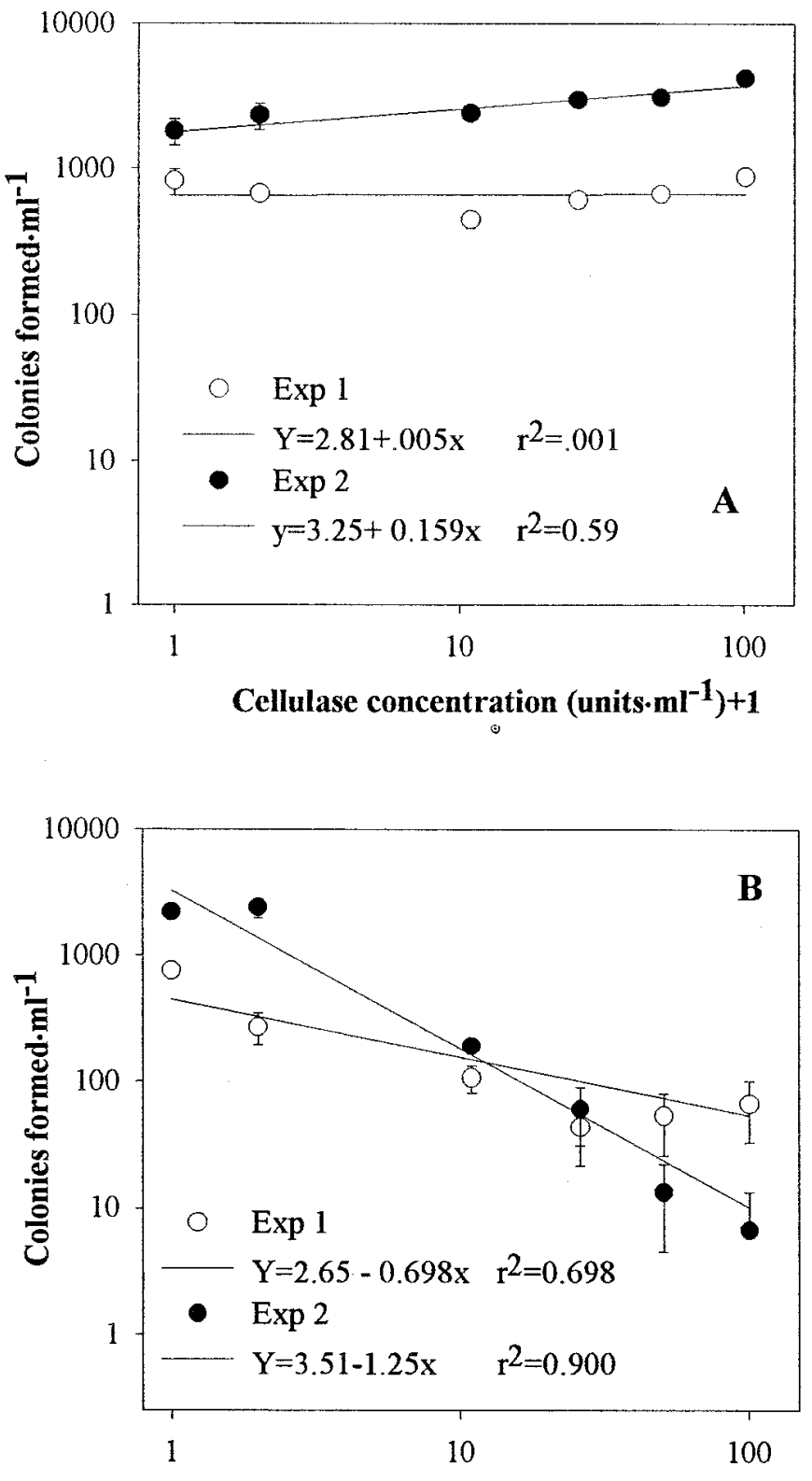

Laminarinase concentration (units. $\mathrm{m}^{-1}$ ) +1

Fig. 9. Effect of enzymes on zoospore survival of Phytophthora cinnamomi. Bars are standard error of the mean of three replicates. 
direct effect on the zoospores because zoospores contain $\beta-1,3$ glucan, substrate is abundant, and enzymatic attack proceeds to destroy the cell.

Chlamydospores are thick-walled resistant spores that survive long periods of drought or nonhost conditions. Chlamydospores formed inside dead root tissues are shielded from enzymatic effects in soil. Only the highest concentration of cellulase known to completely dissolve Phytophthora cinnamomi mycelium was effective against chlamydospores in roots. Thick-walled chlamydospores inside plant roots may require considerable enzymatic digestion to cause lysis of these spore cell walls. However, intermediate concentrations were not studied. Low concentrations of cellulase or laminarinase stimulated colony formation of chlamydospore-infested root tips, suggesting enhancement of chlamydospore germination. Yet, if chlamydospores germinate as sporangia and release zoospores, the zoospores would subsequently be killed by the laminarinase concentrations that were stimulatory to chlamydospore germination. This process, regulated by laminarinase, may deplete an organic soil of Phytophthora cinnamomi inoculum before Phytophthora could infect susceptible roots.

Because soils contain many different organisms, substrates, and metabolites, it is logical that most or all enzyme components are present; however, some may be low in concentration. The addition of substrate stimulates growth of fungi and production of enzymes. As saprophytic fungi attack the substrate, microbial and enzyme activities increase (11). Continuous addition of cellulosic mulches in avocado groves (the Ashburner system) maintains high substrate availability for saprophytic fungi and their enzyme systems and stimulates biological control. The observations made in this study are consistent with our previous observations (10) that enzyme-mediated control of Phytophthora cinnamomi in mulch systems may be an important aspect of biological control in the Ashburner system.

\section{LITERATURE CITED}

1. Abdel-Sater, M. A. 1994. Cellulase activity and succession of fungi in soil amended with sodium chloride, organic matter and Ca-superphosphate. J. Basic Microbiol. 34:283-302.

2. Ayers, W. A. 1971. Induction of sporangia in Phytophthora cinnamomi by a substance from bacteria and soil. Can. J. Microbiol. 17:1517-1523.

3. Ayers, W. A., and Zentmyer, G. A. 1971. Effect of soil solution and two soil pseudomonads on sporangium production by Phytophthora cinnamomi. Phytopathology 61:1188-1193.

4. Bartnicki-Garcia, S. 1966. Chemistry of hyphal walls of Phytophthora. J. Gen. Microbiol. 42:57-69.

5. Bartnicki-Garcia, S., and Lippman, E. 1973. Fungal cell wall composition. Pages 229-252 in: Handbook of Microbiology. A. I. Laskin and H. A. Lechevaluer, eds. CRC Press, Cleveland.

6. Bartnicki-Garcia, S., and Wang, M. 1983. Biochemical aspects of morphogenesis in Phytophthora. Pages 121-137 in: Phytophthora, Its Biology, Taxonomy, Ecology, and Pathology. D. C. Erwin, S. BartnickiGarcia, and P. H. Tsao, eds. The American Phytopathological Society, St. Paul, MN.

7. Broadbent, P., and Baker, K. F. 1974. Association of bacteria with sporangium formation and breakdown of sporangia in Phytophthora spp. Aust. J. Agric. Res. 25:139-145.

8. Brown, A. E., Finlay, R., and Ward, J. S. 1987. Antifungal compounds produced by Epicoccum purpurascens against soil-borne plant pathogenic fungi. Soil Biol. Biochem. 19:657-664.

9. Cook, R. J., and Baker, K. F. 1983. The Nature and Practice of Biological Control of Plant Pathogens. The American Phytopathological Society, St. Paul, MN.

10. Downer, A. J., Menge, J. A., and Pond, E. C. 1997. An enzymatic mechanism for biological control of Phytophthora cinnamomi Rands using mulch. (Abstr.) Phytopathology 87(suppl.):S25.

11. Downer, A. J., Menge, J. A., and Pond, E. 2001. Association of cellulytic enzyme activities in eucalyptus mulches with biological control of
Phytophthora cinnamomi. Phytopathology 91:847-855.

12. Elad, Y., Chet, I., and Henis, Y. 1982. Degradation of plant pathogenic fungi by Trichoderma harzianum. Can. J. Microbiol. 28:719-725.

13. El-Tarabily, K. A., Sykes, M. L., Kurtboke, I. D., St. J. Hardy, G. E., Barbosa, A. M., and Dekker, R. F. H. 1995. Synergistic effects of a cellulase-producing Micromonospora carbonacea and an antibioticproducing Streptomyces violascens on the suppression of Phytophthora cinnamomi root rot of Banksia grandis. Can. J. Bot. 74:618-624.

14. Erwin, D. C., and Ribeiro, O. K. 1996. Phytophthora Diseases Worldwide. The American Phytopathological Society, St. Paul, MN.

15. Fang, J. G., and Tsao, P. H. 1995. Efficacy of Penicillium funiculosum as a biological control agent against Phytophthora root rots of azalea and citrus. Phytopathology 85:871-878.

16. Finlay, A. R., and McCracken, A. R. 1991. Microbial suppression of Phytophthora cinnamomi. Pages 383-398 in: Phytophthora. J. A. Lucas, ed. University Press, Cambridge.

17. Fridlender, M., Inbar, J., and Chet, I. 1993. Biological control of soilborne plant pathogens by a $\beta-1,3$ glucanase-producing Pseudomonas cepacia. Soil Biol. Biochem. 25:1211-1221.

18. Hemmes, D. E. 1983. Cytology of Phytophthora. Pages 9-40 in: Phytophthora: Its Biology, Taxonomy, Ecology, and Pathology. D. C. Erwin, S. Bartnicki-Garcia, and P. H. Tsao, eds. The American Phytopathological Society, St. Paul, MN.

19. Henis, Y., and Chet, I. 1975. Microbiological control of plant pathogens. Adv. Appl. Microbiol. 19:85-111.

20. Kellam, M. K., and Coffey, M. D. 1985. Quantitative comparison of the resistance to Phytophthora root rot in three avocado rootstocks. Phytopathology 75:230-234.

21. Madi, L., Katan, T., and Henis, Y. 1992. Inheritance of antagonistic properties and lytic enzyme activities in sexual crosses of Talaromyces flavus. Ann. Appl. Biol. 121:565-576.

22. Malajczuk, N. 1983. Microbial antagonism to Phytophthora. Pages 197218 in: Phytophthora: Its Biology, Taxonomy, Ecology, and Pathology. D. C. Erwin, S. Bartnicki-Garcia, and P. H. Tsao, eds. The American Phytopathological Society, St. Paul, MN.

23. Menyonga, J. M., and Tsao, P. H. 1966. Production of zoospore suspensions of Phytophthora parasitica. Phytopathology 56:359-360.

24. Nesbitt, H. J., Malajczuk, N., and Glenn, A. R. 1979. Effect of organic matter on the survival of Phytophthora cinnamomi Rands. in soil. Soil Biol. Biochem. 11:133-136.

25. Ribeiro, O. 1983. Physiology of asexual sporulation and spore germination in Phytophthora. Microbial antagonism to Phytophthora. Pages 55-70 in: Phytophthora: Its Biology, Taxonomy, Ecology, and Pathology. D. C. Erwin, S. Bartnicki-Garcia, and P. H. Tsao, eds. The American Phytopathological Society, St. Paul, MN.

26. Schirmbock, M., Lorito, M., Wang, Y. L., Hayes, C. K., Arisan-Atac, I., Scala, F., Harman, G., and Kubicek, C. 1994. Parallel formation and synergism of hydrolytic enzymes and peptaibol antibiotics, molecular mechanisms involved in the antagonistic action of Trichoderma harzianum against phytopathogenic fungi. Appl. Environ. Microbiol. 60: 4364-4370.

27. Sinsabaugh, R. L., Antibus, R. K., and Linkins, A. E. 1991. An enzymic approach to the analysis of microbial activity during plant litter decomposition. Agric. Ecosyst. Environ. 34:43-54.

28. Sivan, A., and Chet, I. 1989. Degradation of fungal cell walls by lytic enzymes of Trichoderma harzianum. J. Gen. Microbiol. 135:675-682.

29. Tateno, M. 1987. Limitations of available substrates for the expression of cellulase and protease activities in soil. Soil Biol. Biochem. 20:117118.

30. Tsao, P. H. 1969. Studies on the saprophytic behavior of Phytophthora parasitica in soil. Proc. 1st Int. Citrus Symp. 3:1221-1230.

31. Tsao, P. H. 1970. Applications of vital fluorescent labeling technique with brighteners to studies of saprophytic behavior of Phytophthora in soil. Soil Biol. Biochem. 2:247-256.

32. Yeoh, H. H., Tan, T. K., and. Tian, K. E. 1984. Cellulolytic enzymes of fungi isolated from wood materials. Mycopathologia 87:51-55.

33. Zentmyer, G. A. 1965. Bacterial stimulation of sporangium production in Phytophthora cinnamomi. Science 150:1178-1179.

34. Zentmyer, G. A. 1981. The effect of temperature on growth and pathogenesis of Phytophthora cinnamomi and on growth of its avocado host. Phytopathology 71:925-928.

35. Zevenhuizen, L. P. T. M., and Bartnicki-Garcia, S. 1970. Structure and role of a soluble cytoplasmic glucan from Phytophthora cinnamomi. J. Gen. Microbiol. 61:183-188. 